\title{
PERANCANGAN FASILITAS KERJA DI BAGIAN PRODUKSI PT. XYZ DENGAN MENGGUNAKAN MACROERGONOMIC ANALYSIS AND DESIGN (MEAD)
}

\author{
Mangara M. Tambunan ${ }^{1}$, Dini Wahyuni ${ }^{1}$, Joseph Kristanto ${ }^{2}$ \\ Dosen Departemen Teknik Industri ${ }^{1}$, Alumni Departemen Teknik Industri ${ }^{2}$ \\ Fakultas Teknik, Universitas Sumatera Utara \\ Jl. Almamater Kampus USU, Medan 20155 \\ Email : mangara_tambunan@yahoo.com \\ Email: diniwahyuni2015@gmail.com \\ Email : joshkristanto92@yahoo.com
}

\begin{abstract}
Abstrak. Fasilitas kerja yang baik merupakan salah satu faktor terpenting dalam kemajuan perusahaan dan merupakan kunci utama keberhasilan dalam rangka mengurangi risiko cidera. Perbaikan fasilitas kerja yang bersifat makro meliputi perbaikan lingkungan kerja, organisasi kerja perusahaan, alat kerja dan postur kerja. Pada penelitian yang dilakukan di PT. XYZ yang bergerak dalam bidang produksi barang plastik seperti jeriken plastik dan celengan plastik. Permasalahan terlihat pada posisi duduk operator ketika menginspeksi produkproduk yang dihasilkan mesin injection moulding. Operator duduk dengan postur kerja yang dapat melelahkan operator. Menurut Grandjean, posisi duduk rendah dengan tanpa sandaran dapat memberikan pengaruh ke tulang belakang lebih besar daripada posisi berdiri tegak. Hal ini dapat memberikan pengaruh ke tulang lumbran 3 dan lumbran 4 yang dapat mengakibatkan terjadinya kifosis ataupun lordosis terhadap tulang belakang operator dalam jangka panjang. Hasil wawancara menyatakan 13 dari 15 operator mengeluh sakit punggung yang disebabkan kursi kerja. Dengan menggunakan metode Macroergonomic Analysis and Design (MEAD) terdapat 9 langkah yang akan dihubungkan dengan penelitian ini untuk menilai dan meningkatkan sistem kerja. Sehingga diperoleh usulan perbaikan fasilitas kerja yaitu kursi kerja memiliki spesifikasi berbentuk kursi kaki tetap, bahan rangka dari kayu, bahan sandaran dari kain, bahan alas dari kain, warna rangka coklat, warna sandaran biru, warna alas biru, daya tahan kursi minimal 3 tahun dan fungsi tambahan sebagai wadah peletakan produk. Dimensi kursi kerja mesin besar memiliki spesifikasi yang hampir sama dengan kursi mesin kecil dengan perbedaan pada tinggi kaki kursi yaitu 89,5 cm pada kursi mesin besar dan 40,3 cm untuk kursi mesin kecil. Meja kerja mesin besar memiliki spesifikasi yang hampir sama dengan meja kerja mesin kecil dengan perbedaan pada tinggi kaki meja yaitu $117,5 \mathrm{~cm}$ pada meja mesin besar dan $62,8 \mathrm{~cm}$ pada meja mesin kecil. Pada metode kerja usulan, operator mengangkat keranjang yang berisikan produk ke meja untuk diinspeksi. Hal tersebut dapat menghilangkan aktivitas membungkuk yang terjadi pada kondisi aktual karena wadah peletakan produk berada di lantai. Keluhan operator yang mengeluh pada bagian punggung, pinggang dan leher juga telah berkurang setelah terjadinya perbaikan fasilitas kerja.
\end{abstract}




\section{Pendahuluan}

Sistem kerja yang baik merupakan salah satu faktor terpenting dalam kemajuan perusahaan, dan merupakan kunci utama keberhasilan dalam rangkamengurangi risiko cidera. Pada mulanya rancangan sistem kerja berawal dari sebuah analisis dalam skala mikro. Seiring dengan perkembangan teknologi serta terjadinya persaingan global di segala aspek, penilaian ergonomi yang bersifat mikro sulit dijalankan bahkan banyak terjadi kegagalan dalam penyelesaian masalah pada lingkungan yang kompleks sehingga diperlukan pendekatan holistik (Purnomo, 2012). Perbaikan sistem kerja yang bersifat makro meliputi perbaikan lingkungan kerja, organisasi kerja perusahaan, alat kerja dan postur kerja.

Hendrick dan Kleiner (2001) berpendapat bahwa dalam ergonomi makro kajian yang dibahas meliputi struktur organisasi, interaksi antara orangorang yang ada dalam organisasi dan aspek motivasi dari pekerja. Menurut Widodo et al. (2012), sebuah sistem kerja harus dapat menjamin keamanan, kesehatan dan keselamatan kerja, serta mampu memenuhi kebutuhan hidup mendasar. Sistem kerja tidak ergonomis akan menyebabkan penurunan produktivitas dan peningkatan kelelahan kerja. Kelelahan kerja dapat terjadi apabila otot menerima beban statis secara berulang dalam waktu yang lama, akan dapat menyebabkan keluhan berupa kerusakan pada sendi, ligamen dan tendon yang dikenal dengan Musculoskeletal disorsders (MSDs) atau cedera pada sistem musculoskeletal (Tumanggor, et al., 2013).

Permasalahan terlihat pada posisi duduk operator ketika menginspeksi produk-produk yang dihasilkan mesin injection moulding. Operator duduk dengan postur kerja yang dapat melelahkan operator. Menurut Grandjean, posisi duduk rendah dengan tanpa sandaran dapat memberikan pengaruh ke tulang belakang lebih besar daripada posisi berdiri tegak. Hal ini dapat memberikan pengaruh ke tulang lumbran 3 dan lumbran 4 yang dapat mengakibatkan terjadinya kifosis ataupun lordosis terhadap tulang belakang operator dalam jangka panjang

Dilakukan wawancara tentang fasilitas kursi kerja yang ada pada lantai produksi untuk melihat seberapa besar keluhan operator. Hasil wawancara menyatakan 13 dari 15 operator mengeluh sakit punggung yang disebabkan kursi kerja. Hasil wawancara menunjukkan ada permasalahan dari keluhan operator yaitu fasilitas kerja tidak memadai, pekerjaan statis terlalu lama, dan kedudukan mesin terlalu tinggi/rendah. Untuk menentukan besarnya pengaruh permasalahan terhadap masalah yang ada maka dilakukan wawancara dengan kepala bidang produksi dan 2 supervisor bidang produksi. Hasil penilaian dapat dilihat pada Tabel 1 .

Tabel 1. Penilaian Permasalahan Keluhan Operator

\begin{tabular}{|c|c|c|c|c|c|}
\hline No & $\begin{array}{c}\text { Akar } \\
\text { Permasa } \\
\text { lahan }\end{array}$ & $\begin{array}{c}\text { Respon } \\
\text { den 1 }\end{array}$ & $\begin{array}{c}\text { Respon } \\
\text { den 2 }\end{array}$ & $\begin{array}{c}\text { Respon } \\
\text { den 3 }\end{array}$ & $\begin{array}{c}\text { Rata- } \\
\text { rata }\end{array}$ \\
\hline 1 & $\begin{array}{c}\text { Fasilitas } \\
\text { kerja tidak } \\
\text { memadai }\end{array}$ & $60 \%$ & $65 \%$ & $60 \%$ & $\begin{array}{c}61,67 \\
\%\end{array}$ \\
\hline 2 & $\begin{array}{c}\text { Pekerjaan } \\
\text { statis terlalu } \\
\text { lama }\end{array}$ & $25 \%$ & $25 \%$ & $30 \%$ & $\begin{array}{c}26,67 \\
\%\end{array}$ \\
\hline 3 & $\begin{array}{c}\text { Kedudukan } \\
\text { mesin } \\
\text { terlalu } \\
\text { tinggi/ } \\
\text { rendah }\end{array}$ & $15 \%$ & $10 \%$ & $10 \%$ & $\begin{array}{c}\% \\
\%\end{array}$ \\
\hline
\end{tabular}

Dari hasil penilaian tersebut, yang menjadi akar permasalahan utama dengan nilai lebih dari 50\% adalah fasilitas kerja tidak memadai Pekerjaan statis yang terlalu lama juga menyebabkan sakit tulang belakang pada operator. Misi PT.XYZ adalah meningkatkan kesejahteraan dan kenyamanan kerja terhadap semua personel yang ada di PT.XYZ. Dengan menggabungkan misi di PT. XYZ dengan keluhan yang dialami operator maka diusulkan suatu peracangan fasilitas kerja dengan metode Macroergonomic Analysis and Design (MEAD) sedangkan untuk memperbaiki pekerjaan statis yang terlalu lama akan diusulkan metode kerja usulan terhadap operator.

\section{Pembahasan}

Penelitian ini dilakukan di PT. XYZ yang bergerak dalam bidang produksi barang plastik seperti jeriken plastik dan celengan plastik. Penelitian ini adalah suatu penelitian deskriptif analisis kerja dan aktivitas (job and activity analysis) yang ditujukan untuk menyelidiki secara terperinci aktivitas dan pekerjaan seseorang atau sekelompok orang agar mendapatkan rekomendasi untuk berbagai keperluan seperti mendapatkan keseimbangan beban kerja antar karyawan, penentuan standar pengupahan, standar prestasi kerja dan lain-lain. Objek penelitian yang diamati adalah operator proses inpeski PT. XYZ

Pengumpulan data dilakukan dengan menggunakan instrumen SNQ dan kuisioner SNQ yang disebar untuk melihat keluhan bagian tubuh pada operator yang hasilnya akan mengarah ke perancangan produk kursi kerja dan meja kerja. Kuisioner yang disebarkan meliputi kuisioner semi terbuka dan tertutup untuk mengetahui variabel 
perancangan produk terhadap konsumen sebanyak 15 orang.

\subsection{Hasil Macroergonomic Analysis and Design}

Terdapat 9 langkah metode MEAD yang akan dihubungkan dengan penelitian ini untuk menilai dan meningkatkan sistem kerja yaitu:

1. Langkah 1: Mendefinisikan subsistem organisasi

Tahap ini bertujuan untuk menentukan uraian proses produksi,struktur organisasi dan visi misi dari PT. XYZ.

2. Langkah 2: Mendefinisikan tipe alat dan menetapkan tingkat kinerja yang diinginkan Penentuan fasilitas kerja pada PT. XYZ merujuk pada perancangan fasilitas yang berbasis kebutuhan dan dimensi tubuh penggunanya. Sesuai dengan misi PT. XYZ untuk meningkatkan kesejahteraan dan kenyamanan kerja terhadap operator yang bekerja maka ditentukan pencapaian yang menjadi sasaran. Tingkat Perfomansi yang ingin dicapai adalah:

a. Menurunkan kelelahan kerja yang dirasakan oleh operator produksi di PT. XYZ.

b. Meningkatkan kesejahteraan dan kenyamanan kerja operator produksi di PT. XYZ.

3. Langkah 3: Mendefinisikan proses kerja dan analisa kerja.

Proses pembuatan produk plastik di PT. XYZ tediri dari 8 tahap yaitu pemilahan bahan baku, pencucian dan penyaringan, penjemuran, pencampuran warna, pencetakan, inspeksi, perakitan dan pengemasan. Proses kerja yang dianalisis adalah bagian inspeksi. Operator bekerja pada posisi tubuh membungkuk yang disebabkan oleh kursi kerja yang rendah dan tidak memiliki sandaran. Wadah peletakan produk juga sangat rendah sehingga operator harus membungkuk saat meletakkan produk yang telah diinspeksi. Pekerjaan dilakukan dalam jangka waktu yang lama, yaitu lebih dari 8 jam per hari.

Berdasarkan identifikasi terhadap proses kerja tersebut, maka dilakukan analisa kerja dengan menggunakan SNQ. Dari hasil identifikasi keluhan musculoskeletal SNQmenunjukkan bahwa keluhan yang paling sering dirasakan pekerja terdapat pada anggota tubuh bagian punggung, pinggang dan leher. Posisi tubuh yang tidak alamiah dan cara kerja yang tidak ergonomis dalam waktu lama dan terus-menerus dapat menyebabkan berbagai gangguan kesehatan pada pekerja antara lain: a. Menurunnya motivasi dan kenyamanan kerja.

b. Gangguan gerakan pada bagian tubuh tertentu (kesulitan menggerakan kaki, tangan atau leher/kepala)

c. Dalam waktu lama bisa terjadi perubahan bentuk tubuh seperti tulang miring dan bengkok.

4. Langkah 4: Mendefinisikan variansi aktual dan harapan

Berdasarkan informasi yang diperoleh dari manager produksi melalui wawancara dan melakukan penyebaran kuesioner SNQ pada pekerja di lantai produksi PT. XYZ. Didapatkan pekerja mengalami keluhan di bagian punggung, pinggang dan leher. Keluhan rasa sakit tersebut disebabkan karena fasilitas kursi kerja yang tidak ergonomis sehingga menyebabkan resiko kerja terhadap operator. Berdasarkan data tersebut maka perlu dilakukan desain kursi kerja yang ergonomis dengan menggunakan data dimensi tubuh pekerja agar dapat menurunkan keluhan kerja yang dialami oleh pekerja dan memberikan keselamatan dan kesehatan kerja serta dapat menyejahterakan pekerja di PT. XYZ.

5. Langkah 5: Membuat matriks variansi

Hasil penilaian yang diperoleh dari kuesioner penilaian dihubungkan dengan karakteristik teknik untuk mendapatkan matriks variansi. Matriks variansi dapat dilihat pada Gambar 1 .

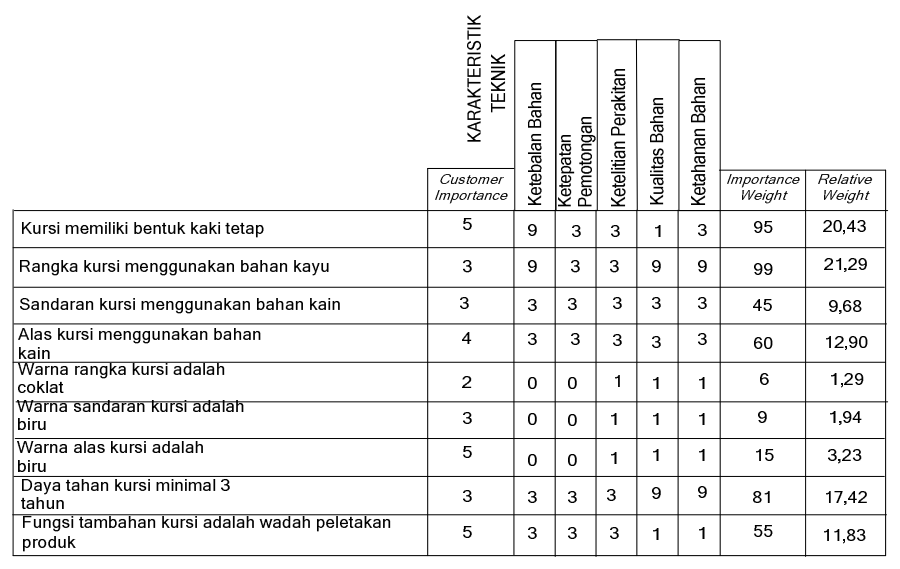

Gambar 1. Matriks Variansi Kursi Kerja

Atas dasar variansi di atas maka spesifikasi kursi kemudian diusulkan kepada pihak manajemen di PT. XYZ untuk dirancang suatu fasilitas kursi yang baru.

6. Langkah 6: Menganalisa peran personel

Pada tahap keenam dalam MEAD bertujuan untuk mengidentifikasi bagaimana variansi yang didapat dari langkah sebelumnya dihubungkan 
dengan peran personel yang bertanggung jawab pada unit kerja yang ada. Kendali varians dan analisis peran personel dapat dilihat pada Tabel 2.

Tabel 2. Kendali Varians dan Analisis Peran Personel

\begin{tabular}{|c|c|c|c|c|}
\hline No & Variansi & $\begin{array}{c}\text { Modus } \\
\text { Kuesioner }\end{array}$ & $\begin{array}{l}\text { Pihak yang } \\
\text { Mengawasi }\end{array}$ & $\begin{array}{c}\text { Pendapat } \\
\text { Personel }\end{array}$ \\
\hline 1 & $\begin{array}{l}\text { Bentuk } \\
\text { Kursi }\end{array}$ & $\begin{array}{c}\text { Kursi kaki } \\
\text { tetap }\end{array}$ & $\begin{array}{c}\text { Kepala } \\
\text { Bidang } \\
\text { Produksi }\end{array}$ & $\begin{array}{c}\text { Kursi kaki } \\
\text { tetap }\end{array}$ \\
\hline 2 & $\begin{array}{l}\text { Bahan } \\
\text { Rangka } \\
\text { kursi }\end{array}$ & Kayu & $\begin{array}{c}\text { Kepala } \\
\text { Bidang } \\
\text { Produksi }\end{array}$ & $\begin{array}{c}\text { Aluminiu } \\
\mathrm{m}\end{array}$ \\
\hline 3 & $\begin{array}{l}\text { Bahan } \\
\text { Sandaran } \\
\text { Kursi }\end{array}$ & Kain & $\begin{array}{c}\text { Kepala } \\
\text { Bidang } \\
\text { Produksi }\end{array}$ & Kain \\
\hline 4 & $\begin{array}{l}\text { Bahan } \\
\text { Alas Kursi }\end{array}$ & Kain & $\begin{array}{c}\text { Kepala } \\
\text { Bidang } \\
\text { Produksi }\end{array}$ & Kain \\
\hline 5 & $\begin{array}{l}\text { Warna } \\
\text { Rangka } \\
\text { Kursi }\end{array}$ & Coklat & $\begin{array}{c}\text { Kepala } \\
\text { Bidang } \\
\text { Produksi }\end{array}$ & Abu-abu \\
\hline 6 & $\begin{array}{l}\text { Warna } \\
\text { Sandaran } \\
\text { Kursi }\end{array}$ & Biru & $\begin{array}{c}\text { Kepala } \\
\text { Bidang } \\
\text { Produksi }\end{array}$ & Biru \\
\hline 7 & $\begin{array}{l}\text { Warna } \\
\text { Alas Kursi }\end{array}$ & Biru & $\begin{array}{l}\text { Kepala } \\
\text { Bidang } \\
\text { Produksi }\end{array}$ & Biru \\
\hline 8 & $\begin{array}{l}\text { Daya } \\
\text { Tahan } \\
\text { Kursi }\end{array}$ & 3 tahun & $\begin{array}{l}\text { Kepala } \\
\text { Bidang } \\
\text { Produksi }\end{array}$ & 5 tahun \\
\hline 9 & $\begin{array}{l}\text { Fungsi } \\
\text { Tambahan }\end{array}$ & $\begin{array}{l}\text { Wadah } \\
\text { peletakkan } \\
\text { produk }\end{array}$ & $\begin{array}{l}\text { Kepala } \\
\text { Bidang } \\
\text { Produksi }\end{array}$ & $\begin{array}{l}\text { Wadah } \\
\text { peletakka } \\
\mathrm{n} \text { produk }\end{array}$ \\
\hline 10 & $\begin{array}{l}\text { Fasilitas } \\
\text { Kerja Lain }\end{array}$ & Meja kerja & $\begin{array}{l}\text { Kepala } \\
\text { Bidang } \\
\text { Produksi }\end{array}$ & $\begin{array}{l}\text { Meja } \\
\text { Kerja }\end{array}$ \\
\hline
\end{tabular}

7. Langkah 7: Mengalokasikan fungsi dan penggabungan desain

Dari hasil diskusi dengan kepala bidang produksi di PT. XYZ maka dapat dibuat 2 alternatif produk yang berdasarkan modus kuesioner dan pendapat kepala bidang produksi. Alternatif ini nantinya akan diberikan kepada stakeholder PT. XYZ, yaitu pemilik PT. XYZ untuk ditentukan variansi apa yang menjadi pilihan untuk pendesainan produk kursi kerja.

Langkah selanjutnya adalah melakukan pemilihan terhadap alternatif yang telah dibuat. Sebelum dilakukan pemilihan alternatif tersebut, terlebih dahulu dilakukan penentuan kriteria dari setiap rancangan alternatif.

8. Langkah 8: Menganalisis Persepsi dan Tanggung Jawab Stakeholder
Dari hasil wawancara terhadap pemilik perusahaan PT. XYZ maka dipilih alternatif 1 menjadi spesifikasi fasilitas kerja untuk operator bagian inspeksi PT. XYZ.Alasan dipilihnya alternatif 1 karena biaya alternatif yang lebih murah daripada alternatif 2 sehingga memberikan dampak pengeluaran yang lebih kecil terhadap perusahaan.

9. Langkah 9: Desain ulang dukungan dan menggabungkan subsistem.

Setelah diperoleh alternatif yang akan digunakan untuk perancangan produk, maka dapat dirancang fasilitas kerja.

\subsection{Pembahasan Perancangan Fasilitas Kerja}

Dengan menggabungkan spesifikasi rancangan kursi yang diperoleh dari metode Macroergonomic Analysis and Design (MEAD) serta hasil perhitungan dimensi antropometri terhadap operator maka dirancang suatu fasilitas kerja baru yang dapat dilihat pada Gambar 2. dan Gambar 3.
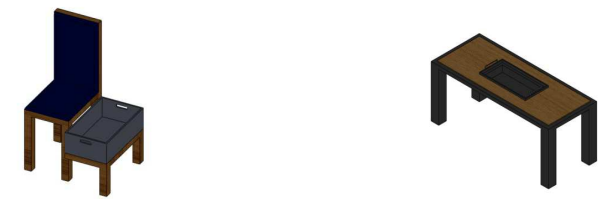

Gambar 2. Usulan Rancangan Fasilitas Mesin Kecil
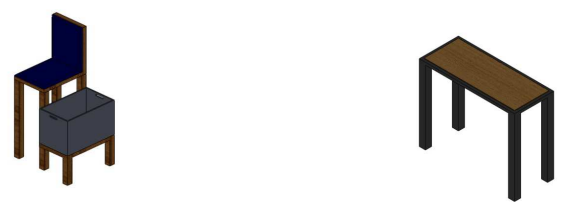

Gambar 3. Usulan Rancangan Fasilitas Mesin Besar

\subsection{Hasil Usulan Metode Kerja}

Usulan fasilitas kerja yang ada membuat terjadinya perubahan metode kerja. Perubahan metode kerja diusulkan untuk operator inspeksi mesin kecil dan untuk operator inspeksi mesin besar. Pada perbaikan metode kerja mesin besar operator tetap menggunakan metode yang ada tetapi dengan perbaikan tinggi fasilitas kerja untuk memudahkan pengambilan produk. Pada perbaikan metode kerja mesin kecil, operator sebelumnya langsung mengambil produk dari keranjang yang terletak di lantai dan langsung menginspeksinya dengan posisi kerja membungkuk. Metode kerja usulan mengganti pekerjaan operator yang mengambil langsung produk tersebut dengan mengangkat keranjang yang berisikan produk ke meja kerja yang ada. 


\subsection{Perbaikan Keluhan Pekerjaan}

Perbaikan sudut duduk operator dapat dilihat dari perbedaan fasilitas kerja yang ada. Fasilitas kerja aktual membuat operator harus membungkuk dan sudut antara pinggang dan paha atas operator naik karena meja dan kursi kerja yang rendah. Setelah dilakukan perbaikan fasilitas kerja, maka operator bekerja dengan lebih nyaman dengan meja dan kursi kerja yang sesuai dengan dimensi tubuh operator sehingga operator tidak perlu lagi membungkuk ataupun duduk dengan sudut antara pinggang dan paha atas yang tinggi.

\subsection{Perbaikan dari hasil SNQ}

Perancangan usulan yang diimplementasikan ke operator PT. XYZ menghasilkan penurunan keluhan terhadap bagian tulang belakang operator. Hal ini dapat dilihat dari hasil identifikasi warna keluhan SNQ usulan. Hasil identifikasi warna keluhan SNQ usulan dapat dilihat pada Gambar 4 Dari hasil gambar keluhan SNQ diperoleh bahwa sudah terjadi perbaikan di bagian tulang belakang. Dari hasil SNQ, terjadi perbaikan keluhan pekerjaan terutama di bagian sakit yaitu pinggang, punggung, dan leher. Hasil rancangan usulan memberikan kenyamanan terhadap operator.

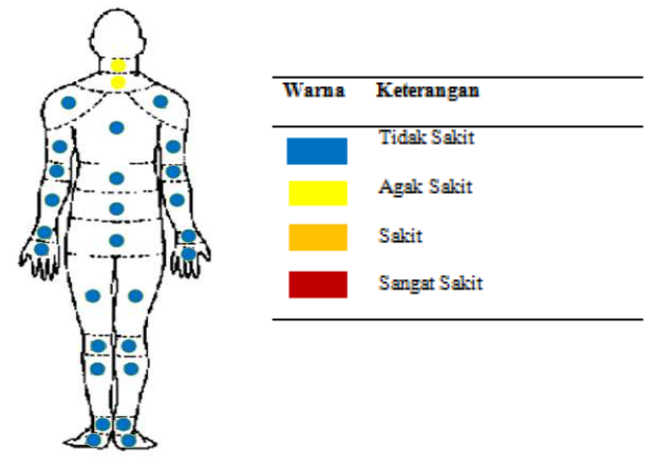

\section{Gambar 4. Hasil Identifikasi Warna Keluhan SNQ Usulan}

\section{Kesimpulan}

Kesimpulan yang didapatkan dari hasil penelitian ini yaitu fasilitas kerja usulan yang berupa kursi kerja dan meja kerja untuk operator inspeksi di PT. XYZ. Kursi kerja usulan memiliki spesifikasi berbentuk kursi kaki tetap, bahan rangka dari kayu, bahan sandaran dari kain, bahan alas dari kain, warna rangka coklat, warna sandaran biru, warna alas biru, daya tahan kursi minimal 3 tahun dan fungsi tambahan sebagai wadah peletakan produk.

Dimensi kursi kerja mesin besar memiliki spesifikasi yang hampir sama dengan kursi mesin kecil dengan perbedaan pada tinggi kaki kursi yaitu $89,5 \mathrm{~cm}$ pada kursi mesin besar dan 40,3 cm untuk kursi mesin kecil. Meja kerja mesin besar memiliki spesifikasi yang hampir sama dengan meja kerja mesin kecil dengan perbedaan pada tinggi kaki meja yaitu $117,5 \mathrm{~cm}$ pada meja mesin besar dan $62,8 \mathrm{~cm}$ pada meja mesin kecil.

Pada metode kerja usulan, operator mengangkat keranjang yang berisikan produk ke meja untuk diinspeksi. Hal tersebut dapat menghilangkan aktivitas membungkuk yang terjadi pada kondisi aktual karena wadah peletakan produk berada di lantai. Keluhan operator yang mengeluh pada bagian punggung, pinggang dan leher juga telah berkurang setelah terjadinya perbaikan fasilitas kerja.

\section{DAFTAR PUSTAKA}

Amalia Suzianti, 2013. Macroergonomic Approach for Improving the Municipal Waste Management System in Jakarta

Ginting, Rosnani. 2009. Perancangan Produk. Edisi Pertama, Yogyakarta: Graha Ilmu.

Grandjean, Etienne. 1988. Fitting the task to the Man. Edisi Empat. London: Taylor and Francis

Hendrick, Hal W. 2002. Macroergonomics Theory, Methods and Applications. Lawrence Erlbaum Associates, New Jersey.

Kleiner, Brian M. 2005. Macroergonomics: Analysis and Design of Worksystems. Department of Industrial and Systems Engineering

Lou Cohen, 1995. Quality Function Deployment:How to Make QFD Work for You, Addison-Wesley Publishing Company, USA

Nely,eprints.undip.ac.id/40974/3/BAB_III.doc 